\title{
Neurolmages
}

\section{VIDE0 Ping-pong gaze in hemifield may indicate bilateral asymmetrical hemispheric lesions}

S.-H. Ahn, MD; K.-D. Choi, MD; J.S. Kim, MD; K.-P. Park, MD; H.-J. Kim, MD; and D.S. Jung, MD, Busan (S.-H.A., K.-D.C., K.-P.P., H.-J.K., D.S.J.) and Seoul (J.S.K.), Korea

A 65-year-old man was found unresponsive at home. Initially, he showed ping-pong gaze only in the right hemifield, which subsequently involved the whole field 2 days later (see video). Other findings included esotropia and bilaterally positive Babinski sign. Diffusion-weighted MRI demonstrated acute infarctions in the right medial frontal and left fronto-temporo-parietal lobes (figure). During the progression of brain herniation, ping-pong gaze changed to fixed gaze deviation to the left, and then to fixed gaze in the midline. Ping-pong gaze in hemifield may result from asymmetric disruption of the cortical inhibitory pathways to the brainstem due to bilateral asymmetric hemispheric lesions. ${ }^{1,2}$

Copyright $\odot 2007$ by AAN Enterprises, Inc.

1. Stewart JD, Kirkham TH, Mathieson G. Periodic alternating gaze. Neurology 1979;29:222-224.

2. Ishikawa H, Ishikawa S, Mukuno K. Short-cycle periodic alternating (ping-pong) gaze. Neurology 1993;43:1067-1070.

Disclosure: The authors report no conflicts of interest.

Address correspondence and reprint requests to Dr. Kwang-Dong Choi, Department of Neurology, College of Medicine, Pusan National University, 1-10 Ami-dong, Seo-gu, Busan, 602-739, Korea; e-mail: kdchoi@ medimail.co.kr

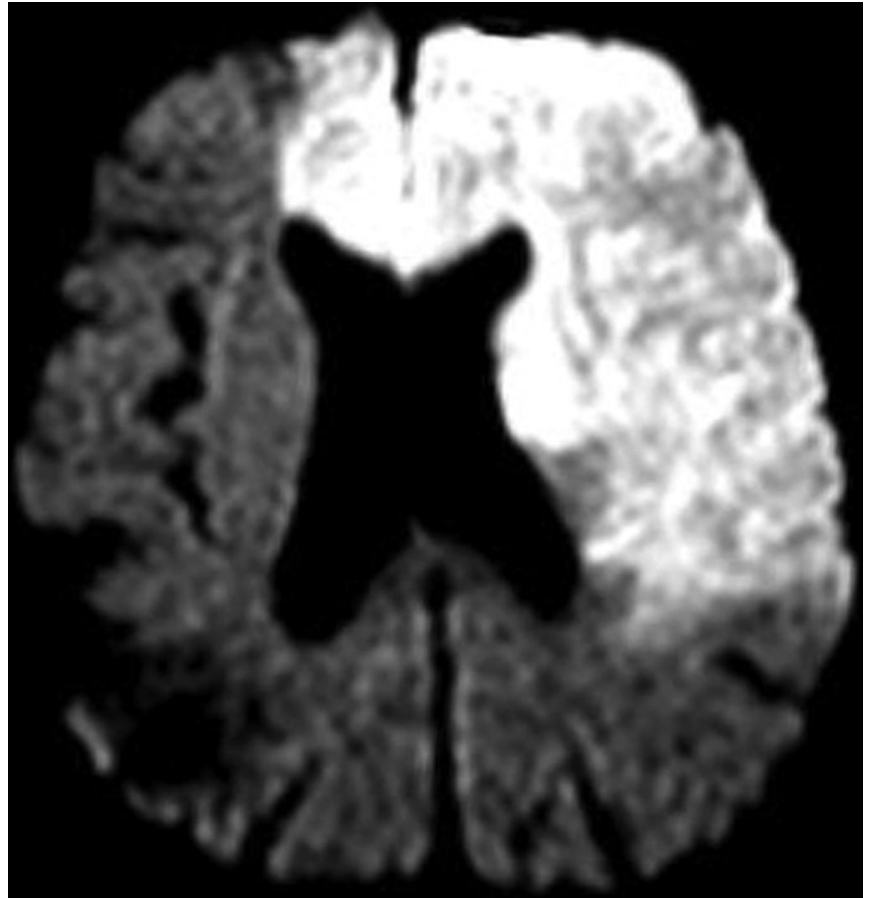

Figure. Diffusion-weighted MRI demonstrates acute infarctions in the right medial frontal and left frontotemporo-parietal lobes. 


\section{Neurology}

Ping-pong gaze in hemifield may indicate bilateral asymmetrical hemispheric lesions S. -H. Ahn, K. -D. Choi, J. S. Kim, et al. Neurology 2007;68;E8

DOI 10.1212/01.wnl.0000256345.01907.09

This information is current as of February 26, 2007

Updated Information \& Services

Supplementary Material

References

Permissions \& Licensing

Reprints including high resolution figures, can be found at: http://n.neurology.org/content/68/9/E8.full

Supplementary material can be found at: http://n.neurology.org/content/suppl/2007/02/13/68.9.E8.DC1

This article cites 2 articles, 2 of which you can access for free at: http://n.neurology.org/content/68/9/E8.full\#ref-list-1

Information about reproducing this article in parts (figures,tables) or in its entirety can be found online at:

http://www.neurology.org/about/about_the_journal\#permissions

Information about ordering reprints can be found online:

http://n.neurology.org/subscribers/advertise

Neurology ${ }^{\circledR}$ is the official journal of the American Academy of Neurology. Published continuously since 1951, it is now a weekly with 48 issues per year. Copyright . All rights reserved. Print ISSN: 0028-3878. Online ISSN: 1526-632X.

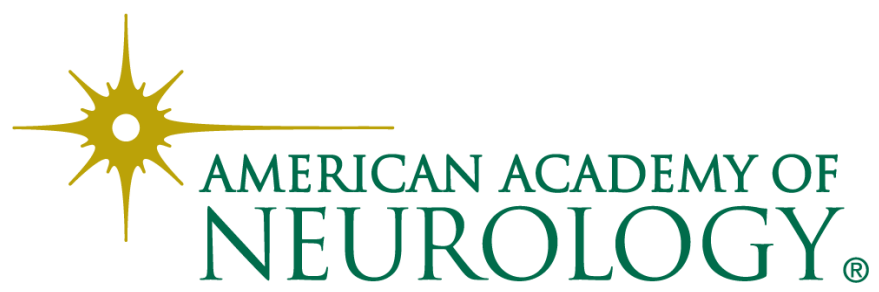

